\title{
Letter from the Editor-in-Chief: Happy 40th Anniversary!
}

\section{Lorraine Eden}

Journal of International Business Studies (2009) 40, I-4. doi: I 0. I057/jibs.2008.88
Congratulations Are in Order... but with a Dollop of Caution The year 2009 is the 40th anniversary of the Journal of International Business Studies. The first volume in 1970 was (not surprisingly) much smaller than IIBS will be this year. Volume 1, edited by Edward W. Ogram, Jr., consisted of two issues, 13 articles and 186 pages. The 2009 volume, for which my 10 editors and I are responsible, will consist of nine issues (up from eight in 2008) with about 70 articles and 1680 pages. The initial print run in 1970 was 300 copies compared to more than 4500 print and online subscriptions in 2008. From little acorns mighty oak trees grow!

Even at 40 years, JIBS is not the oldest journal in the field of international business (IB). Three IB journals are older: Thunderbird International Business Review (TIBR), formerly The International Executive (first published in 1959), Management International Review (MIR) (1961) and Journal of World Business (JWB), formerly Columbia Journal of World Business (1966). The field of IB can now claim half a century of scholarly journal publications.

Despite being younger than its TIBR, MIR and JWB siblings, JIBS for many years has been widely perceived to be the premier scholarly journal in the field of IB. Moreover, JIBS is now regularly ranked among the top 10 scholarly business and management journals; the most recent Social Sciences Citation Index places JIBS seventh among business journals and tenth among management journals. We have much to celebrate.

Still, JIBS is now one journal among many journals that list IB either as their sole or an important domain - and the field is becoming more crowded. Both the number of specialty IB journals and the number of mainstream business journals publishing IB articles continue to grow. Journals widely recognized as top-ranked business journals (e.g., Academy of Management Journal, Strategic Management Journal) now regularly publish articles that could have appeared in JIBS.

Many universities and business schools around the world recognize the field of IB as a distinct scholarly area, with the Academy of International Business (AIB) as its lead institution and JIBS as its premier journal. In most business schools, including many top-tier institutions, a research portfolio that includes JIBS publications now often goes a long way towards earning tenure and promotion. On the other hand, in the 1990s some universities - including some high-profile US business schools - closed their IB departments and scattered their faculty among mainstream areas in accounting, finance, marketing and management. When IB 
scholars are housed in a non-IB department, they are typically expected to publish in their own department's core journals; faced with tenure and promotion pressures, JIBS can become their second or third publication choice. AIB members are called upon regularly to explain the significance of the AIB and JIBS in a world filled with scholarly organizations that already have an IB component such as the Academy of Management and the Strategic Management Society. Thus, while on balance the credibility of IB as a scholarly field has improved considerably over the past 50 years, the struggle against the older mainstream areas remains.

Therefore, while a 40th anniversary is a marvelous event to celebrate - and we will celebrate the event with several activities in 2009 - as JIBS Editorin-Chief, I and my editorial team must always be mindful of the competitive, fast-moving landscape that surrounds us. We must continually strive to increase the visibility and stature of the journal not only among IB journals but also among top-ranked journals in all disciplines that include IB as a subject domain. As our Statement of Editorial Policy says, the goal of JIBS - within this universe of journals - must be to publish the most insightful and influential research on international business.

\section{JIBS@40 Activities}

The JIBS editorial team has planned two key activities to celebrate the journal's 40th anniversary. The first is the JIBS40th/AIB50th Anniversary issue, "Innovations in International Business Theory", which celebrates both the 50th anniversary of the AIB in 2008 and the 40th anniversary of JIBS in 2009. The key criteria for articles in this JIBS Special Issue, which will appear later this year, are their innovativeness and potential contribution to IB theory. Second, the JIBS editors have decided to extend the JIBS Decade Award from 1987 (the most recent JIBS volume for which a Decade Award was given) backwards in time to 1970. Winning articles for 1970 through 1986 will be announced and their authors will be honored at the annual AIB meetings in San Diego in June 2009.

Other notable JIBS activities that will appear in the journal in 2009 include, first, the publication of two special themed sections/issues of the journal, one on "Offshoring Administrative and Technical Work" and another on "Asia and Global Business in the 21st Century". Second, two new Calls for Papers have been launched, one on "Conflict, Security and Political Risk: International Business in Challenging Times" (papers currently under review) and a second on "Qualitative Research in International Business" (papers due in September 2009). Third, the JIBS editors are preparing additional Letters from the Editors, which will appear in later issues of the journal on topics including "Student samples in international business research", "Avoiding a desk reject", and "How international is JIBS?"

A major activity for the JIBS editors in fall 2008 was the selection of two new editorial boards. These boards are critical components of the journal review process. The Consulting Editors Board (CEB) guest edits and provides reviews of manuscripts; the Editorial Review Board (ERB) is our primary source of reviewers for JIBS submissions. The original CEB and ERB members completed their terms in December 2008; new board members will serve from January 2009 through December 2010. We are very grateful that so many leading IB scholars are willing to give of their time and resources to JIBS.

At the 2008 AIB meetings in Milan, JIBS gave its first-ever Best Reviewer Awards to the top 10 best reviewers for the journal; we will give a second set of Best Reviewer Awards at the upcoming AIB meetings in San Diego. Also at the meetings, the JIBS editors will offer another daylong Paper Development Workshop, organized by Laszlo Tihanyi and designed to assist AIB members with turning their IB ideas and manuscripts into journal-ready submissions. The JIBS editors will also host two JIBS Decade Award sessions, one for the 2009 JIBS Decade Award winner and a second celebrating all winners of the JIBS Decade Award back to 1970 .

Finally, in addition to handling more than 500 journal submissions a year, my editors and I continue to speak regularly on behalf of the journal at a variety of universities, conferences and doctoral/junior faculty consortia. ${ }^{1}$ You can read more about the editorial team's activities and download presentations at http://cibs.tamu.edu/jibs/ activities.html.

\subsection{Highlights}

As in previous years, the first issue of JIBS for the year begins with a reprint of the JIBS Decade Awardwinning article, a Retrospective by the author or authors, and one or more invited Commentaries. In an Anniversary year, it is serendipity but perhaps not surprising that the 2008 Decade Award went to an article written by the world's best-known IB 
scholar: John H. Dunning. The award-winning article is "Location and the Multinational Enterprise: A Neglected Factor?" originally published in JIBS volume 29.1.

The JIBS Decade Award, sponsored by Palgrave Macmillan, is designed to recognize the most influential JIBS paper published in the volume 10 years prior, and is presented at the annual AIB conference. The 2008 Selection Committee members were Thomas Murtha (Chair), John Cantwell (2008 AIB Program Chair), Oded Shenkar (2007 AIB Program Chair), with myself as an ex officio member. A special JIBS Decade Award session honoring John Dunning was held at the 2008 Milan AIB meetings. The session was chaired by Thomas Murtha and began with a short videotape of Rajneesh Narula interviewing John Dunning about his 1998 article. Presentations by John Cantwell, Alan Rugman and myself were followed by John Dunning's own remarks. The Decade Award session was videotaped, and both videos will be available to AIB members from the AIB website.

Revised versions of the Dunning and Cantwell presentations appear in this issue of JIBS. The Decade Award article reprint is first followed by a Retrospective by John Dunning that traces the history of his research on location theory and the multinational enterprise (MNE), setting it in the context of key issues and events of the day facing MNE scholars and managers. Looking forward, Dunning then develops in some detail what he sees as worldwide trends and normative implications of the "L factor" in the foreseeable future. He concludes that $\mathrm{L}$ advantages are becoming increasingly contextual, forcing scholars to adopt a more co-evolutionary and interdisciplinary approach that incorporates institutional factors. Some of Dunning's ideas are old, others new, and all provocative.

Next follows a Commentary by John Cantwell, which argues that Dunning's 1998 paper was a critical turning point and catalyst that brought location issues back to center stage in IB scholarship. ${ }^{2}$ Some of the new locational issues that Cantwell explores include asset-seeking FDI, competence-creating subsidiaries within the MNE network, FDI spillovers in host countries, the tension between the "death of distance" and the importance of local clusters, how MNEs can create super additive competitive advantage, MNE networks as evolutionary learning organizations, problems of adverse selection in local clusters, liability of foreignness, and institutional distance.
The remainder of JIBS 40.1 consists of seven articles, of which five were accepted for publication by former Editor-in-Chief Arie Y. Lewin, one transitioned between editorial teams and was completed under my editorship (the Dastidar article), and one was submitted and completed under my editorship (the article by Arregle, Beamish and Hébert). Several of these articles focus on location and the MNE.

The first article, by Asmussen, Pedersen and Dhanaraj, "Host-country environment and subsidiary competence: Extending the diamond network model", is a nice follow-up to the Decade Award set of articles. The authors ask "How do local environments influence the competitive advantage of firms?" and reach three insightful conclusions. First, host-country environmental strength is multi-dimensional and varies along three dimensions: supply, technical and market. Unbalanced diamonds exist, where one dimension is strong and the others weak, but MNEs can compensate for weaknesses by operating across countries that are strong in different dimensions. Second, subsidiary competencies are multi-dimensional; as a result, the center-of-excellence concept is "too coarse" and should be replaced by the concept of subsidiary competence configuration. Lastly, host-country environment configuration is positively linked with subsidiary competency configuration, but moderated by geographic proximity to headquarters and the subsidiary's resource contribution to the MNE network. Thus, the article builds on Dunning's L advantage, extends the Porter diamond and Rugman-Verbeke double diamond frameworks, and contributes to our understanding of Ghoshal and Nohria's work on the MNE as a differentiated network.

The second article, by Buckley and Hashai, "Formalizing internationalization in the eclectic paradigm", is the first general-equilibrium model to formalize internationalization in the OLI paradigm. O (ownership), L (location) and I (internalization) are modeled as continuous variables. Relationships among these variables create inequalities that generate necessary and sufficient conditions for the emergence of MNEs. For those among us who remember the hot debates in the 1980s and early 1990s about whether O was either necessary or sufficient for the emergence of an MNE, and whether $\mathrm{O}$ was distinct or subsumed within $\mathrm{I}$, this article is for you. In addition to solving these old debates, the authors update the OLI paradigm by modeling asset-seeking as well as asset-exploiting 
FDI. The authors show how their formalization can enable scholars to empirically test the OLI paradigm, and suggest several extensions.

The next three papers deal with the relationship between multinationality and firm performance. Dastidar, in "International corporate diversification and performance: Does firm self-selection matter?" argues that researchers must control for endogeneity when studying the multinationality-performance relationship. Arregle, Beamish and Hébert in "The regional dimension of MNEs' foreign subsidiary localization" find that the regional dimension is important and separate from the country dimension of the multinationality-performance relationship. The third article, by Bouquet, Morrison and Birkinshaw, "International attention and multinational enterprise performance", argues that international attention (the extent to which headquarters executives invest time and effort in understanding the global marketplace) has an inverted $U$ shape with MNE performance.

The last two papers in this issue focus on downstream (marketing) issues within the MNE network. "Developing successful trust-based international exchange relationships", by Katsikeas, Skarmeas and Bello, explores the linkages between trust and performance in international buyer-supplier relations. "A transaction cost rationale for private branding and its implications for the choice of domestic vs offshore outsourcing", by Chen, employs the concept of brand specificity to explore private branding and its implications for the retailer's decision to outsource production to domestic vs foreign suppliers.

Issue 40.1 therefore "sets the bar high" in terms of insightful and influential research on IB. We intend to maintain and raise the bar in subsequent issues. Enjoy ... and Happy Anniversary! ${ }^{3}$

\section{NOTES}

${ }^{1}$ Two AIB activities related to the journal that will happen in 2009 should also be mentioned. First is the upcoming AIB Frontiers Conference, organized by Kendall Roth and Mike Shealy at the University of South Carolina, to be held from December 3 to December 5 in Charleston, South Carolina, on the theme "International Business Research and the Transformation of the Public-Private Boundary". The AIB Executive has taken over responsibility for the Frontiers Conferences, decoupling them from JIBS. The second activity will be the call and selection of a new Editor-in-Chief by the AIB Executive Board. Since my term is over in December 2010, a new JIBS editor should be selected in late 2009, with the new team starting to handle submissions in July 2010 . For more information on both activities, please see the AIB website at http://aib.msu.edu.

${ }^{2}$ Both the Dunning Retrospective and the Cantwell Commentary were single blind reviewed by the JIBS editors and selected members of the Consulting Editors Board.

${ }^{3}$ I thank Alain Verbeke for his helpful suggestions with respect to this EIC letter. 